\author{
3. Д. Воробець, М. Є. Кушинська, О. Я. Чупашко
}

Львівський національний медичний університет імені Данила Галицького

\title{
ОКРЕМІ СТОРІНКИ ІСТОРІЇ МЕДИЧНОЇ БІОЛОГІЇ У ЛЬВІВСЬКОМУ НАЦІОНАЛЬНОМУ МЕДИЧНОМУ УНІВЕРСИТЕТІ ІМЕНІ ДАНИЛА ГАЛИЦЬКОГО
}

\author{
Z. D. Vorobets, M. Ye. Kushynska, O. Ya. Chupashko \\ Danylo Halytskyi Lviv National Medical University \\ SOME PAGES OF MEDICAL BIOLOGY HISTORY AT DANYLO \\ HALYTSKYI LVIV NATIONAL UNIVERSITY
}

\begin{abstract}
Мета роботи - відтворення основних етапів життєвого шляху Михайла Івановича Єфімова, завідувача кафедри медичної біології (1946-1948), наукового дослідника проблеми регенерації органів і тканин.

Основна частина. Колективом кафедри проведено комплексне ретроспективне дослідження із залученням архівних матеріалів, поодиноких повідомлень, що збереглись у наукових виданнях того часу, що дало змогу відтворити сторінки становлення кафедри, її наукових спрямувань упродовж періоду від створення донині. Дане наукове повідомлення є суттєвим доповненням історико-медичного минулого сучасної України. Організатором і першим завідувачем кафедри медичної біології Львівського медичного інституту був Рудольф Вейгль - гуманіст, патріот, вчений, що створив першу у світі ефективну вакцину від висипного тифу. 31946 до 1948 р. кафедру очолював Михайло Іванович Єфімов. У даній статті наведено біографічні дані М. Єфімова. Також представлено результати його наукових досліджень стосовно вирішення актуальної наукової проблеми - регенерації органів і тканин.

Висновок. Упродовж існування кафедри медичної біології Львівського національного медичного університету ім. Данила Галицького (з 1920 р. дотепер) ії очільниками були визначні вчені, які провадили багатоаспектні наукові дослідження, що $є$ вагомим внеском у розвиток не лише української, а й світової біологічної науки.
\end{abstract}

Ключові слова: висипний тиф; медична біологія; регенерація; М. І. Єфімов; Р. Вейгль.

The aim of the work - investigation and reconstruction of the main stages of Michael Efimov's life. He was the head of the Medical Biology Department (1946-1948) and a scientific researcher of the organs and tissues regeneration problems.

The main body. We made an integrated and retrospective research with involvement of archive materials, which remained in scientific publications at that time. These archive materials enable to reproduce the pages of development of the department, its scientific direction from establishment and until today. This scientific message is significant addition to historical and medical past of the modern Ukraine. Rudolf Weigl was an organizer and the first head of Medical Biology Department at Lviv National Medical University. He was a humanist, patriot, scientist, who created the first in the world effective typhus vaccine. Michael Yefimov was the head of the department from 1946 till 1948. In this article a data about Michael Yefimov were highlighted. Also in this article the results of his scientific researches about the solution of the problem of regeneration of organs and tissues are represented.

Conclusion. During the existence of the Medical Biology Department at Lviv National Medical University (from 1920 until today), its heads were outstanding scientists, who conduct multidimensional scientific researches and contributed into development not only Ukrainian, but into world medical biology.

Key words: typhus; medical biology; regeneration; Michal Yefimov; Rudolf Weigl.

Вступ. Світоглядна позиція фахівця-медика формується не лише на основі знань $з$ теоретичних медико-біологічних і клінічних дисциплін, але й спрямована на орієнтування майбутніх лікарів на загальнолюдські гуманістичні цінності. Кожна навчальна дисципліна, що передбачена програмою для студентів вищих медичних та фармацевтичних закладів освіти, окрім набуття професійних знань і навичок, несе елемент гуманітарного виховання. Поміж історичних аспектів розвитку медицини в Україні поглиблене вивчення історії медичної біології має значення з огляду на те, що ця навчальна дисципліна $є$ теоретичною основою медицини і від ії вивчення певною мірою залежать подальші успіхи у діагностиці, лікуванні i, насамперед, попередженні тих чи інших захворювань.

(ㄱ 3. Д. Воробець, М. Є. Кушинська, О. Я. Чупашко 
У 2020 р. кафедра медичної біології Львівського національного медичного університету ім. Данила Галицького буде відзначати своє 100-річчя. Колективом кафедри проведено комплексне ретроспективне дослідження із залученням архівних матеріалів, поодиноких повідомлень, що збереглись у наукових виданнях того часу, що дало змогу відтворити сторінки становлення кафедри, її наукових спрямувань упродовж періоду від створення донині.

Мета роботи - відтворення основних етапів життєвого шляху Михайла Івановича Єфімова, завідувача кафедри медичної біології (1946-1948), наукового дослідника проблеми регенерації органів і тканин.

Основна частина. Гортаючи сторінки історії, перед нами постає велика постать Рудольфа Вейгля - організатора і першого завідувача кафедри медичної біології, гуманіста, патріота, вченого, який працював щоденно на теренах науки в ім'я поліпшення якості життя і здоров'я людини, і про якого можна справедливо сказати: "Подвиг завдовжки життя”. Видатний біолог, паразитолог, мікробіолог, імунолог, професор Рудольф Вейгль (1883-1957) очолював кафедру до 1944 р., і за період завідування кафедрою зробив вагомий внесок у вирішення проблеми профілактики та лікування висипного тифу, створив першу у світі ефективну вакцину від висипного тифу [3, 7, 8, 11]. Відомий вчений, лауреат Нобелівської премії Чарльз Ніколь писав: “Здавалось, що “війна” з тифом не обіцяє успіхів, поки до неї не долучився видатний вчений, професор Рудольф Вейгль зі Львова. Вейгль навчив нас, як культивувати збудника тифу у воші, i, більш того, розробив високоякісну вакцину, яка врятувала багато людських життів. Як особистість, найрозумніша людина, невтомний працівник і фанат науки Вейгль заслуговує на найвище визнання” [10, 12].

У 1946 р. кафедру медичної біології очолив професор Михайло Іванович Єфімов і працював на цій посаді до 1948 р. [2, 9]. Життєвий шлях М. Єфімова почався в селі Мале Коров'я Чухломського району Ярославської губернії, де він народився 9 жовтня 1906 р. Батьки займались сільським господарством, торгівлею, батько служив у Шкірсиндикаті. Спочатку М. Єфімов навчався в школі ІІ ступеня села Чухломе, а по смерті батьків (батько помер, коли Єфімову виповнилося 14 років, а мати - через 4 роки) переїхав до Москви. 31926 до 1927 р. працював на різних тимчасових роботах, але прагнув до знань і особливий інтерес виявляв до біологічної науки.
Тому спочатку вступив на медичний факультет 2-го Московського медичного інституту, а з 1931 до 1934 р. навчався у 1-му Московському державному університеті на біологічному факультеті. 3 грудня 1935 р. працював асистентом кафедри загальної біології Хабаровського медичного інституту. 3 вересня 1935 р. до вересня 1942 р. - завідувачем кафедри біології Сталінградського медичного інституту. Кандидатську дисертацію за темою "Регенераційний процес органа як процес розвитку частини в цілому” М. Єфімов захистив у 1935 р., і цього ж року йому присвоєно науковий ступінь кандидата медичних наук і вчене звання доцента [5].

За період роботи в Сталінградському медичному інституті працював на курсах факультету підвищення кваліфікації професорсько-викладацького складу, провадив наукову роботу за темою "Регенерація тканин і органів”, активно публікувався у фахових наукових виданнях, завершив експериментальну частину докторської дисертації.

У зв’язку із військовими діями 23 серпня 1942 р. Сталінградський медичний інститут підлягав евакуації в м. Чебоксари Чуваської республіки, але переселення не відбулося, оскільки шлях на Волзі був перекритий німецькими окупантами. На цей час М. Єфімов був одружений, мав двох неповнолітніх дітей (3 і 6 років), а також хворого старого тестя, тому він прийняв рішення залишитися в окупованому Сталінграді і почав лікувати поранених військовополонених. У жовтні цього ж року було ліквідовано шпиталь військовополонених і йому запропонували переїхати в Україну.

3 листопада 1942 р. до вересня 1943 р. М. І. Єфімов мешкав в окупованому німцями Павлограді Дніпропетровської області, завідував хірургічним кабінетом та працював дільничним лікарем. Після звільнення Павлограда у вересні 1943 р. був прикликаний до лав діючої Червоної армії і служив там до закінчення війни. Під час служби отримав 5 нагород.

Навіть у роки війни М. Єфімов активно продовжував наукову роботу і у другій половині 1945 р. подав до захисту дисертацію на здобуття наукового ступеня доктора біологічних наук до спеціалізованої Вченої ради 2-го Московського медичного інституту. 20 березня 1946 р., вже працюючи у Львові, M. I. Єфімов захистив дисертацію за темою “Регенераційна територія передньої кінцівки у аксолотля і механіка виникнення регенерата” на звання доктора біологічних наук [6]. Одним із опонентів М. І. Єфімова був Леонід Якович Бляхер, завідувач 
кафедри загальної біології 2-го Московського медичного інституту, ембріолог та історик науки, доктор біологічних наук, професор, член Міжнародної академії історії науки (з 1966 р.), учень академіка М. М. Завадовского [1]. Професор Л. Я. Бляхер потрапив, як і багато інших вчених, під переслідування тодішньої влади. 24 серпня 1949 р. був звільнений від завідування кафедрою загальної біології згідно з наказом міністра освіти і міністра охорони здоров’я. В наказі було сказано: “Звільнити професора Л. Я. Бляхера від роботи завідувача кафедрою загальної біології 2-го Московського державного медичного інституту як активного прихильника і пропагандиста реакційного вейсмановсько-менделевсько-морганівського напряму в біології, і призначити на цю посаду професора біолога-мічурінця”. Після звільнення Л. Я. Бляхер почав працювати над історією морфології тварин.

Другим опонентом М. І. Єфімова був Лев Давидович Ліознер, працював на посаді асистента, а $з$ 1940 р. - доцента кафедри загальної біології 2-го Московського медичного інституту. За цей час він захистив кандидатську (1936) і докторську (1940) дисертації. На кафедрі займався проблемою регенераційних можливостей різних тканин при відновленні органів, дослідженням ролі гормонів у формотворчих процесах тощо [4]. У 1946 р., після його звільнення з інституту, зрозуміло, через національну ідеологію, йому вдалося влаштуватися в Інститут експериментальної біології Академії медичних наук, в лабораторію росту і розвитку, якою завідувала М. А. Воронова - дружина Л. Д. Ліознера. Однак через чотири роки адміністрація вирішила неприпустимим перебування в одній лабораторії чоловіка і дружини, в результаті чого Лев Давидович був звільнений “за скороченням штатів”. Півроку він залишався без роботи, бо тоді вже йшла боротьба з “безрідними космополітами”, а ще це був час після сумнозвісної сесії ВАСГНІЛ, на якій нищівній критиці з боку тодішнього президента ВАСГНІЛ Т. Лисенка підлягли так звані менделісти-морганісти, після чого практично припинились генетичні дослідження, а керівники відповідних профільних лабораторій, інститутів були звільнені 3 посад. Врешті-решт його прийняли в Головне управління навчальних закладів МОЗ РРФСР старшим методистом, де завідував методичним кабінетом.

Ще одним опонентом М. І. Єфімова був Микола Григорович Хрущов, радянський гістолог, цитолог, академік РАН (член-кореспондент АН СРСР 3
1979 р.). Він - син члена-кореспондента АН СРСР Г. К. Хрущова, онук активіста партії конституційних демократів К. Р. Хрущова, тому уник репресій тамтешньої влади.

28 березня 1946 р. М. І. Єфімова прийнято на посаду завідувача кафедри біології Львівського медичного інституту, а 12 липня 1947 р. Єфімову присуджено вчене звання професора. Колектив кафедри того часу налічував 7 осіб (1 професор, 2 доценти, 2 асистенти, 2 лаборанти). У період завідування М. І. Єфімова кафедрою біології у Львівському медінституті співробітники кафедри відійшли від проблеми висипного тифу і зайнялись проблемою регенерації органів і тканин. На кафедрі біології М. І. Єфімов організував гурток, у якому студенти проводили науково-дослідну роботу з даної проблеми. Слід зазначити, що студенти з великим бажанням відвідували лекції професора М. Єфімова, бо читались вони професійно, і лектор володів великим ораторським мистецтвом. За час роботи у медичному інституті М. Єфімов опублікував 14 наукових праць, зокрема "Роль шкіри в процесі регенерації органа...”, “Чи можна змінити шляхи розвитку клітин молодої бластоми при перенесенні її на іншу ампутаційну ранову поверхню” тощо [6]. Навіть невеликий перелік публікацій М. Єфімова свідчить про наукову інтуїцію, бо важко переоцінити важливість та актуальність проблеми регенерації органів. Адже сутність будь-якого патологічного процесу полягає в ушкодженні структур організму. Знання механізмів регуляції регенерації дозволить відновлювати структурні елементи, впливаючи на різні ланки регуляторного процесу. Проте професор Єфімов працював на кафедрі лише два роки. На цей час директором Львівського державного медичного інституту був доктор медичних наук, ортопед-травматолог із Душанбе Г. Ф. Скосогоренко. Він, як і більшість радянських професорів, запроваджував прийняті тоталітарним режимом закони науки і навчання студентів, викладання російською мовою, виховання молодого покоління на комуністичних ідеях. Якщо в університеті до радянського періоду дипломи наукового ступеня i наукові звання присвоювали професори вчених рад університету, то тоталітарно-більшовицький режим запровадив кардинальні зміни автономії і статусу університетів та інститутів, питання наукових ступенів і звань стали оформлятися в Москві ВАКом за участі партійних органів, спецчастин НКВС, управління міністерства. Г. Скосогоренком було відряджено в Павлоград П. Матковського для до- 
питу колишніх співробітників М. Єфімова стосовно того, чим займався М. І. Єфімов у м. Павлограді за часу німецької окупації. Він провів бесіду з I. Кубицьким, Ф. Півнем, А. Перуновою. Кубицький та Перунова дали позитивну характеристику лікарю М. Єфімову, однак у їхніх поясненнях було зазначено, що в нього був конфлікт із Ф. Півнем. Власне, Ф. Півень дав показання стосовно співпраці Єфімова з окупаційною владою. Водночас на початку серпня 1948 р. відбулась сумнозвісна сесія ВАСГНІЛ. Усі ці події, вочевидь, стали реальною причиною звільнення М. Єфімова з посади завідувача кафедри біології, і це відбулось 3 листопада 1948 р. $з$ формулюванням - у зв’язку із незабезпеченням керування кафедрою. Але вже 26 листопада цього ж року було опубліковано зміни до поперед-

\section{Список літератури}

1. Бляхер Л. Я. Этюды по истории морфологии (I) / Л. Я. Бляхер // Анналы биологии. - 1959. - Т. 1. С. 155-264.

2. Ганіткевич Я. Українські лікарі-вчені першої половини XX століття та їхні наукові школи. Біографічні нариси та бібліографія / Я. Ганіткевич. - Львів : В-во НТШ, 2002. - 542 с.

3. Зіменковський Б. С. Професори Львівського національного медичного університету імені Данила Галицького: 1784-2006 / Б. С. Зіменковський, М. Р. Гжегоцький, О. Д. Луцик. - Львів : Наутілус, 2006. - 416 с.

4. Лиознер Л. Д. Основные проблемы учения о регенерации / Л. Д. Лиознер. - М. : Наука, 1975. - 124 с.

5. Львівський обласний державний архів, ф. 26, оп. 12, од. зб. 469, л. 6-8.

6. Львівський державний медичний інститут. 210-річчю відкриття, 100-річчю відновлення медичного факультету у Львові присвячується. - Львів, 1994. - 328 с.

7. Середа О. М. Кафедра медичної біології Львівського національного медичного університету імені Дани- нього наказу: “Звільнити професора М. І. Єфімова від роботи завідувачем кафедрою у зв’язку з переходом на роботу в інший медінститут” [5].

На захист професора стали студенти медичного інституту, які скерували листа міністру освіти Кафанову. Проте позитивного результату не отримали, і Михайло Єфімов, боячись арешту, залишив Україну і виїхав до Середньої Азії. Подальша доля М. Єфімова невідома.

Висновок. Упродовж існування кафедри медичної біології Львівського національного медичного університету ім. Данила Галицького (з 1920 р. дотепер) її очільниками були визначні вчені, які провадили багатоаспектні наукові дослідження, що $є$ вагомим внеском у розвиток не лише української, а й світової біологічної науки.

ла Галицького: історичні та наукові аспекти розвитку / О. М. Середа, О. Я. Чупашко, 3. Д. Воробець // Медична освіта. - 2009. - № 3. - С. 57-60.

8. Середа О. М. Професор Рудольф Вейгль і його внесок у розвиток соціальної медицини та медичної біології / О. М. Середа, 3. Д. Воробець // Укр. мед. часопис. 2009. - Т. 74, № 6. - С. 108-111.

9. Шапиро И. Я. Очерки по истории Львовского медицинского института / И. Я. Шапиро. - Львов : ЛГМИ, 1959. - 135 c.

10. Ben Nefissa K. Charles Niccole's theory on the natural history of infectious diseases / K. Ben Nefissa // Arch. Inst. Pasteur Tunis. - 2006. - Vol. 83, No. 1-4. - P. 5-12.

11. Hnatush S. Professor R. S.Weigl and Scientific center in Lviv / S. Hnatush, R. Stoika // $2^{\text {nd }}$ Polish-Ukrainian conference "Microbiology in the XXI certury". - Warsaw, 2007. - P. 34-37.

12. Krynski S. Rudolf Weigl (1883 - 1957) / S. Krynski // Med. Dosw. Microbiol. - 1967. - No. 9. - P. 233-239.

3. Zimenkovskyi, B.S., Hzhehotskyi, M.R., \& Lutsyk, O.D. (2006). Profesory Lvivskoho nacionalnoho medychnoho universytetu imeni Danyla Halytskoho: 1784-2006 [Professors of Danylo Halytskyi Lviv National Medical University: 1784-2006]. Lviv: Nautilus [in Ukrainian].

4. Liozner, L.D. (1975). Osnovnye problemy ucheniya $o$ regeneratsii [The main problems of the theory of regeneration]. Moscow: Nauka [in Russian]. 
5. Lviv Regional State Archive [in Ukrainian].

6. Lviv State Medical Institute. The 210-th anniversary of the opening, 100-th anniversary of the restoration of the medical faculty in Lviv is devoted to. (1994). Lviv [in Ukrainian].

7. Sereda, O.M., Chupashko, O.Ya., \& Vorobets, Z.D. (2009). Kafedra medychnoi biolohii Lvivskoho natsionalnoho medychnoho universytetu imeni Danyla Halytskoho: istorychni ta naukovi aspekty rozvytku [Department of Medical Biology, Lviv National Medical University named after Danylo Halytskyi: historical and scientific aspects of development]. Medychna osvita - Medical Education, 3, 57-60 [in Ukrainian].

8. Sereda, O.M., \& Vorobets, Z.D. (2009). Profesor Rudolf Veihl i yoho vnesok u rozvytku sotsialnoi medytsyny ta medychnoi biolohii [Professor Rudolf Weigl and his contribution to the development of social medicine and medical biology] Ukrainskyi medychnyi chasopys Ukrainian Medical Journal 6, 108-111 [in Ukrainian].

9. Shapiro, I.Ya. Ocherki po istorii Lvovskoho meditsinskogo instituta [Essays on the history of the Lviv Medical Institute]. Lvov: LMHI [in Ukrainian].

10. Ben Ne fissa, K. (2006). Charles Niccole's theory on the natural history of infections diseases. Arch. Inst. Pasteur Tunis, 83 (1-4), 5-12.

11. Hnatush, S., Stoika, R. (2007). Professor R. S. Weigl and Scientific center in Lviv. $2^{\text {nd }}$ Polish-Ukrainian conference "Microbiology in XXI century". Warsaw.

12. Krynski, S. (1967). Rudolf Weigl (1883-1957). Med. Dosw. Microbiol., 9, 233-239. 